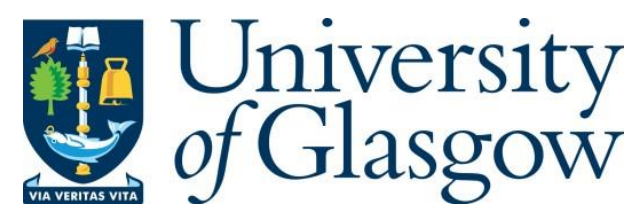

Crilley, R. and Chatterje-Doody, P. (2019) Security studies in the age of 'post-truth' politics: in defence of poststructuralism. Critical Studies on Security, 7(2), pp. 166-170.

There may be differences between this version and the published version. You are advised to consult the publisher's version if you wish to cite from it.

http://eprints.gla.ac.uk/218066/

Deposited on: 24 June 2020

Enlighten - Research publications by members of the University of Glasgow http://eprints.gla.ac.uk 


\section{Security Studies in the age of 'Post-Truth' Politics: In Defence of Poststructuralism}

Dr Rhys Crilley (Open University, UK)

Dr Precious Chaterje-Doody (University of Manchester, UK)

Much has recently been written about how we now live in a global 'post-truth' era (Ball, 2017; d'Ancona, 2017; Davis, 2017) where 'lying is regarded as the norm, even in democracies' (d'Ancona, 2017: 26). Commentators have been quick to point the finger of blame for this era of 'post-truth' politics at postmodernism/poststructuralism. Philosopher Daniel Dennett charged that 'what the postmodernists did was truly evil. They are responsible for the intellectual fad that made it respectable to be cynical about truth and facts' (Dennett quoted in Cadwalladr, 2017). Postmodernism also apparently represents a 'threat not only to liberal democracy but to modernity itself' (Pluckrose, 2017), and academics and journalists alike have suggested that postmodernism laid the groundwork for 'post-truth' politics (Calcutt, 2016; Scruton, 2017). The LSE has even organised a roundtable discussion asking 'Is Post-Modernism to Blame for our Post-Truth World?' (LSE, 2017).

The answer, if you're wondering, is no, and there are several reasons why. First, many of the features of today's 'post-truth' era are not new at all. Politicians have always lied and news reporting has always been biased. Throughout history, political authorities have made the collapsing of fact and fiction a fundamental aspect of their rule (Arendt, 1973: 382); a lot of what we're seeing now has serious precedent. Second, many of the contemporary criticisms of poststructuralism/postmodernism are revivals of debates already well-worn across security studies. Poststructuralism has previously been criticised for lacking a research agenda (Keohane, 1988: 392); for self-indulgent 'navel-gazing' at the expense of engagement with the 'real world' (Walt, 1991: 223); and for its 'rejection of metanarratives and universal solidarities' which makes it useless to people in trouble (Booth, 2005: 270). Now, as then, these critiques don't quite ring true. Just as 'post-truth' politics did not begin in the ivory towers of Paris, so poststructuralism is not poetic philosophising devoid of practical point.

On the contrary, poststructuralism can help with making sense of security in the age of 'post-truth' politics. Poststructuralism presents a host of conceptual and methodological tools helpful for uncovering the conditions of possibility which have allowed the politics of 'post-truth' to thrive. It can also assist in understanding, challenging and changing the contemporary insecurities so bound up with it. Most significantly, you don't have to be a paid-up postie to see where these insights can map on to other approaches, or to derive something useful from the toolkit. As a starting point, this essay explains how several insights of poststructuralism can help us navigate the 'post-truth' security environment.

Poststructuralism is often blamed for the ills of 'post-truth' politics. This argument, however, is 'based on a shallow caricature of the theory and an exaggerated estimation of 
its effects' (Perrin, 2017). Poststructuralism is not a dogma that demands that we all reject 'facts'. The point is rather to recognise how particular ideas and practices gain the status of 'facts' or 'common sense' knowledge as a result of the way in which they are represented, abstracted or interpreted. Key to this process is the issue of power relations, whereby particular understandings and assumptions about all areas of social life, be it science, sexuality, or security, are normalised in place of alternatives. The point, then, of poststructuralism isn't to say that 'anything goes', it is to explore and analyse how "'truths" are mobilized and meted out' (Epstein, 2005: 13). Poststructuralists like Foucault 'recognized the way in which competing narratives about, or constructions of, reality are involved with political power...but that was to identify the problem rather than to cause it' (Leith, 2017).

The solution to 'post-truth' politics and 'fake news' does not lie in the refuting of claims through fact checking and the quest for a more objective notion of truth. Rather, research has shown that fact-checking articles rarely have as much influence as the false claims they set out to debunk, and they actually perpetuate the dissemination of falsehoods to larger audiences (Vargo et al., 2017). Poststructuralism can point us towards a more effective response, based not around attempting to 'reveal essential truths that have been obscured' but rather in examining 'how certain representations underlie the production of knowledge and identities and how these representations make various courses of action possible' (Doty, 1996: 4).

This is important, because it has repercussions in the everyday lived experiences of people across the planet. Poststructuralism has afforded an attention to language, aesthetics, practices, emotions, and the everyday which can help us to understand how real people experience insecurity in the contemporary 'post-truth' era. A case in point here is President Trump's attempt to ban Muslims from certain countries entering the U.S. Such policies have become socially plausible largely because of how Muslims are represented, and have been represented, as threats - particularly during the 'War on Terror' (see Said, 1997; Jackson, 2005). As the experiences of 'fact checkers' bears out, reiterating that Muslims are not by definition a threat is not enough, nor is it likely to be effective.

Here, poststructuralism makes an important contribution. To date, research in security studies that draws upon poststructuralism and postcolonialism has offered precisely the tools with which to uncover, critique and destabilise the representations, knowledge claims and identities that make such racist and Islamophobic policies possible (see for example Heath-Kelly et al., 2014; Fitzgerald et al., 2016). Methods such as genealogy and deconstruction are vital in understanding, critiquing and changing the political, social, technological and cultural conditions which enable the likes of Trump. Trump's rhetoric constructs a notion of American identity which is built upon racial and gendered dichotomies of a white America threatened by a non-white Other; whether that be Mexican 
'rapists' or Islamic 'terrorists'. As a recent range of studies under the auspices of 'critical studies on security' have demonstrated in this very journal, methods of deconstruction and genealogy can help to uncover and challenge these discourses and their impact on security (Bentley et al., 2017; Eroukhmanoff, 2017; Hassan, 2017).

Using tools such as these, it becomes possible to pick apart the structures of inequality, sexism, and xenophobia that have enabled the 'post-truth' policies of politicians like Trump, and have encouraged people to seek out 'alternative' sources of news which speak more to their interests and beliefs. All these phenomena are underpinned by representations that construct knowledge, shape identities, and serve to legitimise certain forms of politics. The success of 'post-truth' politics, populist politicians, and hyper-partisan news providers is not because a group of academics encouraged people to question that which they take for granted. It is because of representations and 'identity; the power of a brand; the prioritizing of a "friendly" or in-group source; the signalling of a claim rather than its factual accuracy; the force of an established narrative, and so on' (Leith, 2017, emphasis in original). In seeking to deconstruct these embedded inequities, poststructuralists trouble some of the core obstacles to alternative forms of politics and offer the means by which those at the sharp end of contemporary structural inequalities can highlight, interrogate, and challenge the conditions of their lived experience.

This is at the core of poststructuralist work. It is not an unrelenting pessimism about the state of the world; it is not a refusal to engage with the 'facts of the matter' - indeed, it is the opposite. For, poststructuralists are intimately concerned with the injustices and inequalities so innocuously entrenched within current ways of thinking, being and doing. That is, they interrogate the ways in which the social structures developed that enabled a politics of 'post-truth' to become not only possible, but also palatable to various groups. Yet, they are also concerned with the contingency of this process, the structures of power and authority that helped it to evolve, and the disruptions to those structures that can open space for alternative ways to develop - an 'inherently positive exercise' (Campbell, 2007: 225). By challenging that which is taken for granted, poststructuralism is in the business of making politics and society less exclusionary, more inclusive, and less contingent on the dominance of the marginalised.

If we are to push for a security studies that works towards helping 'real people in real places' (Booth, 2005: 272) in the era of 'post-truth' politics we should not blame a caricature of poststructuralism for making the world more insecure. Rather we need to take seriously the insights that poststructuralism offers on language, practice, aesthetics, emotions, and the everyday discontents of race, gender, and class and how they intersect in the 'posttruth' era. In providing the toolkit to pick apart these inequities, poststructuralism may just provide a platform for making people more judicious in their media consumption habits, ending racist policies at home and abroad, and for addressing global inequalities. 


\section{References}

Arendt $\mathrm{H}$ (1973) The Origins of Totalitarianism. Mariner Books.

Ball J (2017) Post-Truth: How Bullshit Conquered the World. London: Biteback Publishing.

Bentley M, Eroukhmanoff C and Hackett U (2017) Trump's 100 days: foreign policy and security implications - introduction. Critical Studies on Security Online FirstView: 12.

Booth K (ed.) (2005) Critical Security Studies And World Politics. London: Lynne Rienner Publishers.

Cadwalladr C (2017) Daniel Dennett: 'I begrudge every hour I have to spend worrying about politics'. The Observer, 12th February. Available from:

http://www.theguardian.com/science/2017/feb/12/daniel-dennett-politics-bacteriabach-back-dawkins-trump-interview (accessed 27 September 2017).

Calcutt A (2016) The surprising origins of 'post-truth' - and how it was spawned by the liberal left. The Conversation. Available from: http://theconversation.com/thesurprising-origins-of-post-truth-and-how-it-was-spawned-by-the-liberal-left-68929 (accessed 27 September 2017).

Campbell D (2007) Poststructuralism. In: Dunne T, Kurki M, and Smith S (eds), International Relations Theories: Discipline and Diversity, Oxford: OUP, pp. 203-208.

d'Ancona M (2017) Post-Truth: The New War on Truth and How to Fight Back. 01 edition. London: Ebury Press.

Davis E (2017) Post-Truth: Why We Have Reached Peak Bullshit and What We Can Do About It. Little, Brown.

Doty R (1996) Imperial Encounters: The Politics of Representation in North-South Relations. Minneapolis: University of Minnesota Press.

Epstein C (2005) The Power of Words in International Relations: Birth of an Anti-Whaling Discourse. MIT Press.

Eroukhmanoff C (2017) A feminist reading of Foreign policy under Trump: Mother of All Bombs, wall and the 'locker room banter'. Critical Studies on Security Online FirstView: 1-5.

Fitzgerald J, Ali N and Armstrong M (2016) Editors' introduction: critical terrorism studies: reflections on policy-relevance and disciplinarity. Critical Studies on Terrorism 9(1): $1-11$. 
Hassan O (2017) Trump, Islamophobia and US-Middle East relations. Critical Studies on Security Online FirstView: 1-5.

Heath-Kelly C, Jarvis L and Baker-Beall C (2014) Editors' introduction: critical terrorism studies: practice, limits and experience. Critical Studies on Terrorism 7(1): 1-10.

Jackson R (2005) Writing the War on Terrorism: Language, Politics and Counter-terrorism. Manchester University Press.

Keohane RO (1988) International institutions: two approaches. International studies quarterly 32(4): 379-396.

Leith S (2017) On Post-Truth | How facts became irrelevant in the modern world. TheTLS. Available from: https://www.the-tls.co.uk/articles/public/post-truth-sam-leith/ (accessed 29 September 2017).

LSE (2017) Is Post-Modernism to Blame for our Post-Truth World? London School of Economics and Political Science. Available from: http://www.Ise.ac.uk/Events/2017/10/20171002t1830vSZT/is-post-modernism-toblame-for-our-post-truth-world.aspx (accessed 27 September 2017).

Perrin AJ (2017) Stop Blaming Postmodernism for Post-Truth Politics. The Chronicle of Higher Education. Available from: http://www.chronicle.com/article/Stop-BlamingPostmodernism-for/240845.

Pluckrose H (2017) How French 'Intellectuals' Ruined the West: Postmodernism and Its Impact, Explained. Areo Magazine. Available from:

https://areomagazine.com/2017/03/27/how-french-intellectuals-ruined-the-westpostmodernism-and-its-impact-explained/ (accessed 10 October 2017).

Said EW (1997) Covering Islam: How the Media and the Experts Determine How We See the Rest of the World. Fully Revised Edition edition. London: Vintage.

Scruton R (2017) Post-truth? It's pure nonsense. The Spectator. Available from: https://www.spectator.co.uk/2017/06/post-truth-its-pure-nonsense/ (accessed 29 September 2017).

Vargo CJ, Guo L and Amazeen MA (2017) The agenda-setting power of fake news: A big data analysis of the online media landscape from 2014 to 2016. New Media \& Society: 1461444817712086.

Walt SM (1991) The renaissance of security studies. International Studies Quarterly 35(2): 211-239. 